\title{
Some Good Practices for Reducing Energy Consumption in Hotels: A Comparative Analysis
}

\author{
Mirela ȘTEFĂNICĂ and Gina Ionela BUTNARU \\ " Alexandru Ioan Cuza" University, Iași, Romania
}

Received date: 13 February 2019; Accepted date:13 May 2019; Published date: 18 July 2019

Academic Editor: Dragos Smedescu

Copyright (C) 2019. Mirela ȘTEFĂNICĂ and Gina Ionela BUTNARU. Distributed under Creative Commons CC-BY 4.0

\begin{abstract}
The present paper analyses the solutions adopted in hotel industry with the purpose to identify the good practices for reducing energy consumption in hotels through a comparative approach of Romanian and Italian hotels, by highlighting the similarities and the differences between them. For this purpose, we used a questionnaire as a research instrument, with the help of which we collected the primary data, which were processed with the SPSS programme. The results highlighted the most commonly applied practices in the tourist units investigated for reducing energy consumption. Consequently, we identified the mesures taken by hotel managers regarding the reduction of energy consumption through improving the energetic efficiency, using alternative sources of energy, and also by paying more attention to the lighting. The results of the research confirmed the alternative hypothesis, according to which adopting good practices leads to cost savings.
\end{abstract}

Keywords: Green Practices, Energy Consumption, Energetic Efficiency, Hotel Industry.

Cite this Article as: Mirela ȘTEFĂNICĂ and Gina Ionela BUTNARU (2019)," Some Good Practices for Reducing Energy Consumption in Hotels: A Comparative Analysis" Journal of EU Research in Business, Vol. 2019 (2019), Article ID 985409, DOI: 10.5171/2019.985409 


\section{Introduction}

Hotel industry constitutes one of the main pillars of the tourism sector. Graci and Dodds (2008) mentioned that resource intensive and frequently inefficient systems and operational routines applied in the sector result in considerable environmental impact and indicate an urgent need for more environmentally sound practices and products in the hotel industry.

Analysing the interest and attitude of the companies regarding the environment, Font (2001) classifies the companies in seven categories: the conservationists (they internalise environmental costs on a constantly evolutionist basis, because they understand the dynamics of the phenomena associated with the environment, and they do not use performance in the field of environment as a promotional instrument, because it would generate a surplus of demand, which is not always desired); the leaders (companies who establish environmental standards in the same way as the conservationists, however, as opposed to the latter, they use environmental performances as a promotional instrument); the distractors (they rather use the principle "I can do" than "I must do", and they wish to be perceived as green by focusing on the elements which are easy to perform in the field of the environment); the compliers (they consider environmental regulations as an obstacle in tourism development, the environment not being a priority for them, so that the management deals with it only tangentially); the opportunists (they use the environmental aspects with marketing purposes, operating minor modifications in planning the resources and the management by observing the basic legislation regarding the environment, and they express their interest towards the environment within the mission and the purpose of their activity, which is also promoted by promotion tactics, even if there is no strong basis); the skivers (opportunist companies who, with the purpose of maximising their profit, they ignore elementary responsibilities towards the environment by not observing the legislation, and they also do not signal environmental problems); the cowboys (similar to "the skivers", they promote their tourist products as based on nature, without proving a respectful behaviour towards the environment and the resources used, an attitude easy to approach in tourism compared to other fields, due to the differences among destinations and tourists' education).

Research targeted at resource consumption in tourist accommodation establishments is, however, sparse. This is not satisfactory given that these establishments are high resource consumers, with tourism accommodation having one of the highest environmental impacts of all subsectors in the tourism sector. (Font, Elgammal and Lamond, 2017; Kasim, 2009)

Many studies have emphasized the fact that hotel industry is a high-energy intensive and polluting sector (Cottella, 2011; Bohdanowicz, 2005; Ragab and Meis, 2016; Revilla, Dodd and Hoover, 2001, Vellecco and Mancino, 2010). It has been observed that a hotel produces between 160 and $200 \mathrm{~kg}$ of carbon dioxide $\left(\mathrm{CO}_{2}\right)$ per square meter in order to generate electricity, heating or cooling, in dependence to the type of fuel used. In the case of European hotels, yearly energy consumption is of 39 twh (terawatts per hour) and the emissions are responsible for approximately 13.6 megatons of $\mathrm{CO}_{2}$. Additionally, tourists consume between 170 and 440 liters of water per day and each tourist produces about one $\mathrm{kg}$ of daily waste, of which no more than $60 \%$ is recyclable (Bohdanowicz, 2005).

Kelly and Williams (2007) mentioned that hotels use substantial amount of energy and are one of the most energy intensive facilities with correspondingly high energy costs. They are ranked among the top five in terms of energy consumption in the tertiary building sector (minor only to food services and sales, health care and certain types of offices).

According to Bohdanowicz and Martinac (2007), a certain level of activity in the area of reducing resource use has been observed for quite some time but the motivation for this was related to cost-benefit issues rather than the environment. Furthermore, most of the 
initiatives are still considered to be best practice case studies and not daily routines. The constantly increasing prices of basic commodities, such as energy resources and water, encourage the implementation of energy and water efficiency and conservation measures in hotel facilities.

\section{Research Methodology}

The purpose of this research is to identify the good practices to achieve the reduction of energy consumption, which could represent an important factor for cost savings. These good practices are implemented in the hotels located in north-east of Italy and Romania, too.

The objectives of the research aim to identify the measures undertaken by hotel managers regarding reduction of energy consumption through improving the energetic efficiency, using alternative sources of energy, and also by paying more attention to the lighting.

The hypothesis at the basis of this research is that good practices regarding reduction of energy consumption represent an important factor for cost savings.

Regarding the research method, we chose research through enquiry, because it assures a higher flexibility, and the data and information are obtained quicker than by other methods (Zaiț and Spalanzani, 2006).
The sampling included the establishment of the unit to be researched - hotels located in the north-east of Italy and Romania:

- size of the sample - 43 tourist units (Italy) and 49 tourists' units (Romania).

- selection procedure - we chose a nonrandom method, based on accessibility (the sample includes all tourist units, and all managers, respectively, who accepted to participate in the respective research, because one of the limits of the research is the fact that some hotel managers refused to participate).

At the same stage we also dealt with the preliminary data systematisation and processing with the help of SPSS 23 programme.

\section{Research Results}

The reduction of energy consumption can be realised by improving the energetic efficiency, using alternative sources of energy, and also by paying more attention to the lighting.

In the following we will present the good practices for achieving the reduction of energy consumption according to the objectives. The situation obtained after processing the data is presented in the following tables (table no. 1-3).

\section{Improvement of Energetic Efficiency}

Table 1: Good practices concerning the reduction of energy consumption

\begin{tabular}{|c|c|c|c|c|}
\hline $\begin{array}{c}\text { Reduction of energy } \\
\text { consumption }\end{array}$ & Item & Good practices & $\begin{array}{c}\text { Romania } \\
(\%)\end{array}$ & $\begin{array}{l}\text { Italy } \\
(\%)\end{array}$ \\
\hline \multirow{6}{*}{$\begin{array}{l}\text { Improvement of energetic } \\
\text { efficiency }\end{array}$} & Q1_1 & $\begin{array}{l}\begin{array}{l}\text { Constant monitoring } \\
\text { consumption }\end{array} \\
\end{array}$ & 46.9 & 74.4 \\
\hline & Q1_2 & Constant maintenance of the equipment & 46.9 & 79.1 \\
\hline & Q1_3 & High thermal isolation & 61.2 & 51.2 \\
\hline & Q1_4 & $\begin{array}{l}\text { Turning off the energy consuming sources } \\
\text { when they are not in use }\end{array}$ & 75.5 & 95.3 \\
\hline & Q1_5 & $\begin{array}{l}\text { Installation of a heating-ventilation system } \\
\text { with energetic efficiency }\end{array}$ & 79.6 & 86.0 \\
\hline & Q1_6 & Controlling the thermostat heating & 51.0 & 90.7 \\
\hline
\end{tabular}

Mirela ȘTEFĂNICĂ and Gina Ionela BUTNARU (2019), Journal of EU Research in Business, DOI: $10.5171 / 2019.985409$ 


\begin{tabular}{|l|l|l|l|l|}
\hline & Q1_7 & $\begin{array}{l}\text { Realisation of energetic audit in the last 3 } \\
\text { years }\end{array}$ & 24.5 & 44.2 \\
\hline
\end{tabular}

Source: Authors; Data obtained in SPSS

From the analysis of the table no. 1 and of the figure no.1 above, both in Romania and in Italy a great attention is paid to the reduction of energy consumption by the improvement of energetic efficiency. Consequently, the monitoring of the energy consumption is constantly realised in $46.9 \%$ of the Romanian hotels, and in $74.4 \%$ of the Italian ones, the equipment is well maintained, and the energy consuming sources are turned off when they are not in use - in $75.5 \%$ of the cases in Romania, and in $95.3 \%$ in Italy. Also, in over $79 \%$ of the hotels investigated, energetically efficient heating-ventilation systems are installed in over $50 \%$ of the Romanian hotels, and in $90 \%$ of the Italian ones heating is controlled by thermostat, and over $50 \%$ of the hotels investigated are thermally isolated.

\section{Use of alternative energy sources}

Table 2: Good practices concerning the reduction of energy consumption

\begin{tabular}{|c|c|c|c|c|}
\hline $\begin{array}{c}\text { Reduction of energy } \\
\text { consumption }\end{array}$ & Item & Good practices & $\begin{array}{c}\text { Romania } \\
(\%) \\
\end{array}$ & $\begin{array}{l}\text { Italy } \\
(\%) \\
\end{array}$ \\
\hline \multirow{6}{*}{$\begin{array}{l}\text { Use of alternative } \\
\text { energy sources }\end{array}$} & Q2_1 & Photovoltaic solar systems (solar panels) & 0 & 23.3 \\
\hline & Q2_2 & Systems of transformation of waste into energy & 0 & 2.3 \\
\hline & Q2_3 & Wind energy & 0 & 0 \\
\hline & Q2_4 & Geothermal energy & 0 & 14.0 \\
\hline & Q2_5 & Biogas & 0 & 2.3 \\
\hline & Q2_6 & $\begin{array}{l}\text { Alternative energy delivered by a provider with } \\
\text { an active policy in the field of alternative sources } \\
\text { of energy }\end{array}$ & 0 & 18.6 \\
\hline
\end{tabular}

Source: Authors; Data obtained in SPSS

The use of alternative sources of energy is practised in neither of the Romanian hotels from our sample, as compared to the Italian ones, where in $23.3 \%$ of the hotels the photovoltaic solar systems are used, in 14\% the geothermal energy is used (the area of our sample being rich in geothermal sources), and in $18.6 \%$ of the hotels the alternative energy is delivered by a provider with an active policy in the field of alternative sources of energy.

\section{Lighting}

Table 3: Good practices concerning the reduction of energy consumption

\begin{tabular}{|c|c|l|r|c|}
\hline $\begin{array}{c}\text { Reduction of energy } \\
\text { consumption }\end{array}$ & Item & \multicolumn{1}{|c|}{ Good practices } & $\begin{array}{c}\text { Romania } \\
\text { (\%) }\end{array}$ & $\begin{array}{c}\text { Italy } \\
\text { (\%) }\end{array}$ \\
\hline \multirow{3}{*}{ Lighting } & Q3_1 & Maximum use of natural light & 93.9 & 83.7 \\
\cline { 2 - 6 } & Q3_2 & Use of energetically efficient lighting devices & 75.5 & 93.0 \\
\cline { 2 - 5 } & Q3_3 & $\begin{array}{l}\text { Installation of movement detectors, } \\
\text { temporisers, and potentiometers }\end{array}$ & 51.0 & 95.3 \\
\hline
\end{tabular}

Source: Authors; Data obtained in SPSS

Mirela ȘTEFĂNICĂ and Gina Ionela BUTNARU (2019), Journal of EU Research in Business, DOI: $10.5171 / 2019.985409$ 
The reduction of energy consumption can be obtained by the maximum use of natural light, which happens in $93.9 \%$ of the Romanian hotels, and in $83.7 \%$ of the Italian ones, the use of energetically efficient lighting devices, found in over $75 \%$ of the Romanian hotels, and in over $90 \%$ of the Italian ones, as well as by the installation of some motion detectors, temporisers, or potentiometers existing in almost all the Italian hotels, and in over $50 \%$ of the Romanian ones.

For a clearer emphasising of the results obtained, we also realised the graphical presentation (figure no. 1).

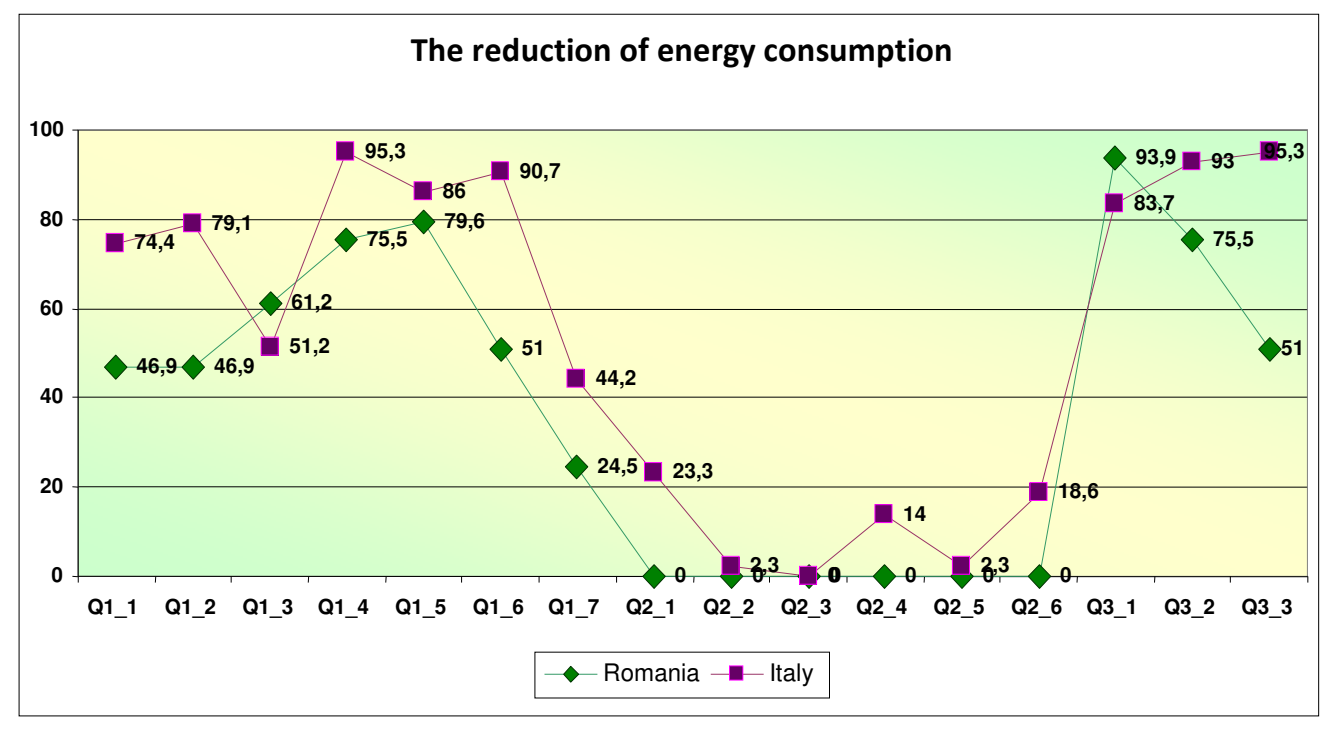

Fig. 1: Good practices concerning the reduction of energy consumption

Source: Authors

At the same time, the managers of these hotels are interested in adopting the good practices to achieve cost savings.

\section{Testing the Hypothesis}

The hypothesis was tested using a nonparametric test - Binomial Test, a procedure used to validate hypotheses regarding one variable with binomial distribution, which can have only two values. For the variables taken into account we calculate the frequencies of appearance of each of the two values, and based on them we calculate the mean, standard deviation. In a few words, Binomial Test is used to compare a proportion with a specified value. By using the Binomial Test, we wanted to verify if the proportion of one of the two groups presented in the table above significantly differed from 0.50 . The sum of the proportions and of the probability of appearance of the two values being one, the probability for any value is 0.50 . Regarding our hypothesis: 
Table 4: Binomial Test

\begin{tabular}{|c|c|c|c|c|c|c|}
\hline & & Category & $\mathbf{N}$ & $\begin{array}{c}\text { Observed } \\
\text { Prop. }\end{array}$ & $\begin{array}{l}\text { Test } \\
\text { Prop. }\end{array}$ & $\begin{array}{l}\text { Asymp. } \\
\text { Sig. (2- } \\
\text { tailed) }\end{array}$ \\
\hline $\begin{array}{l}\text { Which of the following } \\
\text { affirmations is closer to } \\
\text { your point of view as a } \\
\text { hotel representative? }\end{array}$ & $\begin{array}{l}\text { Group } \\
1\end{array}$ & $\begin{array}{l}\text { Good practices for } \\
\text { reducing energy } \\
\text { consumption represent } \\
\text { an important factor for } \\
\text { cost savings. }\end{array}$ & 71 & .78 & .50 & $.000(a)$ \\
\hline & $\begin{array}{l}\text { Group } \\
2\end{array}$ & $\begin{array}{l}\text { Good practices for } \\
\text { reducing energy } \\
\text { consumption do not } \\
\text { represent an important } \\
\text { factor for cost savings. }\end{array}$ & 20 & .22 & & \\
\hline & Total & & 91 & 1.00 & & \\
\hline
\end{tabular}

a Based-on Z Approximation.

Source: Authors; Data obtained in SPSS

The data obtained show that the proportion seen in the sample is $78 \%$, and the proportion specified is $50 \%$. The Sig. value associated to the test is lower than 0.01 , so we can conclude, with a confidence of $99 \%$, that the null hypothesis is rejected, and the alternative hypothesis is confirmed. According to this hypothesis, good practices for reducing energy consumption in hotel industry represent an important factor for cost savings.

\section{Conclusions}

Hotels consume substantial quantity of energy, water and other non-durable products, thus provoking significant environmental impacts. On the other hand, they rely on clean nature and unpolluted environment as a core value for hotel industry. Tourists more often abandon tourism destinations in poor environmental condition and trace for hotels with eco label, eco certificate and certificate for energy efficiency. Consequently, hotel industry is becoming increasingly environmentally responsible by taking care of energy efficiency.

Due to the fact that clean and well-preserved environment is one of the main preconditions for high quality service generally in the hospitality-oriented facility, one may conclude the dependent nature of the hotel development. Most likely, the energy demand will continue growing in the future, so energy planning and use of renewable sources as energy supply alternatives may be a solution for sustainable development.

The research conducted in the hotels of Italy and Romania highlighted that most of the environmental practices are implemented especially by the management of the Italian hotels, where hotel managers seem to be much more aware of the seriousness of the environmental problems, and the necessity to 
adopt measures for their improvement, while in the Romanian hotels they are less present.

Consequently, believe that by this research we managed to identify the degree of involvement of the managers from Italian and Romanian hotel industry in the reducing of energy consumption and we highlighted the good environmental practices adopted in hotel industry.

It would be interesting to see also the costs generated by the application of such measures, or the savings we could make in time. They could be future directions of research.

\section{References}

1. Bohdanowicz, P. and Martinac, I. (2007). 'Determinants and benchmarking of resource consumption in hotels : case study of Hilton International and Scandic in Europe`. Energy and Buildings, 39(1), 82-95.

2. Bohdanowicz, P. (2005) 'European Hoteliers Environmental Attitudes. Greening the Business', [Online] Cornell Hotel and Restaurant Administration Quarterly, Vol. 46, No. 2, pp. 188-204, [Accessed on 12 July 2018] Available: http://journals.sagepub.com/doi/pdf/10.117 7/0010880404273891

3. Buckley, R.C. (2001) 'Major issues in tourism ecolabelling', [Online] in Font, X., Buckley, R.C., (eds.), Tourism Ecolabelling. Certification and Promotion of Sustainable Management, CABI Publishing. [Accessed on 9 February 2019], https://www.cabi.org/cabebooks/ebook/200 13042883

4. Claver-Cortéz, E., Molena-Azorin, F.J., Pereira-Moliner, J., López-Gamero, M.D. (2009) 'Environmental Strategies and Their Impact on Hotel Performance,' . [Online] Journal of Sustainable Tourism, 15(6), [Accessed on 16 January 2019] http://www.tandfonline.com/doi/abs/10.216 $7 /$ jost 640.0
5. Cottella, G. (2011) 'EU Cohesion Policy in the Light of Lisabon and Gothenburg Objectives: The case of Italy; . [Online] [Accessed on 8 February 2019] http://discussionpapers.rkk.hu/index.php/D $\mathrm{P} /$ article/viewFile/2467/4603

6. Font, X. (2001) 'Regulating the green message: the players in ecolabelling,' . [Online] in Font, X., Buckley, R.C., (eds.), Tourism Ecolabelling. Certification and Promotion of Sustainable Management, CABI Publishing. [Accessed on 9 February 2019], https://www.cabi.org/cabebooks/ebook/200 13042883

7. Font, X., Elgammal, I., Lamond, I., (2017). ' Greenhushing: the deliberate under communicating of sustainability practices by tourism businesses', Journal of Sustainable Tourism, 25(7), pp.1007-1023

8. Graci, S., Dodds, R., (2008). 'Why Go Green? The Business Case for Environmental Commitment in the Canadian Hotel Industry', Anatolia, 19(2), pp.251-270

9. Kasim, A., (2009). `Managerial attitudes towards environmental management among small and medium hotels in Kuala Lumpur', Journal of Sustainable Tourism, 17(6), pp.709725

10. Kelly, J. and Williams PW, (2007) Modelling Tourism Destination Energy Consumption and Greenhouse Gas Emissions, Journal of Sustainable Tourism, 15(1), 67-90

11.López-Gamero, M.D., Pertusa-Ortega, E.M., Molina-Azorín, J.F., Tarí-Guilló, J.J., PereiraMoliner, J., (2016). 'Organizational antecedents and competitive consequences of environmental proactivity in the hotel industry', Journal of Sustainable Tourism, 24(7), pp.949-970

12.Ragab, A.M., Meis, S. (2016) `Developing environmental performance measures for tourism using a Tourism Satellite Accounts approach: a pilot study of the accommodation

Mirela ȘTEFĂNICĂ and Gina Ionela BUTNARU (2019), Journal of EU Research in Business, DOI: $10.5171 / 2019.985409$ 
industry in Egypt' Journal of Sustainable Tourism, 24:7, pp.1007-1023

13.Revilla, G., Dodd, T.H., Hoover, L.C., (2001). 'Environmental Tactics Used by Hotel Companies in Mexico', International Journal of Hospitality \& Tourism Administration, 1(3-4), pp.111-127

14.Vellecco, I., Mancino, A. (2010) 'Sustenability and Tourism Development in
Three Italian Destinations: Stakeholders Opinions and Behaviours,' . [Online] The Service Industries Journal, 30(13), 2201-2223, [Accessed on 18 January 2019], http://www.tandfonline.com/doi/abs/10.108 $0 / 02642060903287500$

15.Zaiţ, D., Spalanzani, A. (2006) Cercetarea în economie şi management: repere epistemologice şi metodologice, Economică (ed.), Bucharest. 